Administrative Issues Journal: Connecting Education, Practice, and Research, Summer 2017, Vol. 7, No. 1: 107-121. DOI: 10.5929/2017.7.1.8

\title{
Do leaders' experience and concentration area influence school performance?
}

\author{
Kimberlin Sturgis, Ph.D. \\ Brittanee Shiflett, M.Ed. \\ Tyrone Tanner, Ed.D. \\ Prairie View A\&M University
}

\begin{abstract}
The purpose of this study was to examine the educational background of leaders in small, high poverty, high minority schools in an effort to determine if the leader's concentration area and background were related to the academic success of the students. Through a causal comparative design, a modified version of the Interstate School Leaders Licensure Consortium (ISLLC) SelfAssessment (CCSSO, 2000) was used to collect data from principals and assistant principals to answer the following research questions: Is there a difference between the leader's concentration area (counseling, mathematics, language arts, science, etc.) and school rating? Is there a difference between the number of years of experience and school rating? This study used the Chi Square Test of Independence, a one-way analysis of variance (ANOVA), and a post-hoc comparison to identify differences between the variables and research questions. The findings revealed that two or more years of experience at the same school had a significant impact on the academic rating of the school, while concentration area did not significantly impact the overall academic school rating.
\end{abstract}

Keywords: educational leadership, minority, poverty, tenure, concentration area

T he world is a rapidly changing global society. The educational system must ensure that the proper people and processes are in place to facilitate the development of students who can function effectively within this society. However, current researchers argue that the United States has not taken the kind of action necessary for creating processes to ensure that schools are as successful as schools in some other nations (Mathews, 2011; Spring, 2008; Tucker, 2011a). A recent publication edited by Tucker (2011a) concluded that excuses made for poor student and school performance in U.S. schools are no longer viable. Among excuses illustrated were diversities in language and socioeconomic backgrounds, limited funds per student, and class size. According to Mathews (2011), these excuses suggest that the overall performance scores of all students in a school system are decreased due to the low performance of culturally different students and lack of finances to support the educational system.

STURGIS, SHIFLETT, \& TANNER / DOI: 10.5929/2017.7.1.8 
If the educational system functions properly in providing an effective education, a child's socioeconomic background and living conditions will not be the only deciding factors in his or her success (Spring, 2008). Educational leaders of schools and systems have important roles in putting effective processes in place and monitoring them to ensure that students and schools succeed. Thus, this study examined the impact of the leader on school performance.

When considering the education of students, several factors must be addressed. Regarding schools, "the research evidence consistently demonstrates that the quality of leadership determines the motivation of teachers and the quality of teaching in the classroom" (Harris \& Chrispeels, 2006, p.121). Advocates of education reform suggest that in order for the educational system to be successful, it must be placed at the forefront of all social and political agendas (Tucker, 2011a, b). As demonstrated through such legislation as No Child Left Behind, sometimes true progress results from adequate change (Spring, 2008, p. 488). This legislation attacked the rising problems in the educational system by developing a program that focused on all populations at all levels. It forced educators to examine the needs of the individual child while at the same time scrutinizing achievement per classroom, per teacher, and per student. While unmasking poor performance, this legislation forced all stakeholders to take responsibility for student performance (Waits, Campbell, Gau, Jacobs, Rex, \& Hess, 2006, p. 6). Researchers suggest that to maintain status as a world super power, the United States must successfully educate its children (Spring, 2008; Tucker, 2011a).

A process that effectively improves academic achievement on a national scale is imperative. It is the ethical responsibility of educators to educate students and properly equip them with the necessary tools to sustain this nation. Continued global progress is dependent on the processes embedded in the educational system, a system that must convince individual students to invest in their own learning and their own future. Aspects of such a global process are currently driven by such federal legislation as the Education for All Handicapped Children Act that involves students in decision making for their future and No Child Left Behind, which provides more parent input in the educational needs of their children. Adherence to these processes is dictated through acceptance of federal funding.

However, as the U.S. Constitution traditionally reserves education of citizens to states, a nationally mandated curriculum would be a challenge to the principle of federalism. A global process driven by the states would be more appropriate and is beginning to take shape through the new Common Core State Standards that have been adopted by all states, with the exception of Minnesota, Nebraska, Texas, and Virginia (National Governors Association Center for Best Practices, CCSSO, 2010). The participation of parents and other stakeholders in developing these core standards in language arts and mathematics have implications for guiding families to invest in learning for themselves. By investing in the future of individuals through ensuring that students, respective of their home state, are taught agreed-upon content for success, the educational system invests in the future of the collective society.

The ultimate goal of the educational system is the success of all students (Hawley, 2007). Successful schools are comprised of a culture of active thinkers and learners (Barth, 2006). These schools produce students who are not only academically successful at their current educational level, but also prepared

STURGIS, SHIFLETT, \& TANNER / DOI: 10.5929/2017.7.1.8 
for success at the next level of their educational journey (Goldring, Porter, Murphy, Elliott, \& Cravens, 2007). No longer can schools afford to teach the 21st century student using 20th century tactics if the intention is to maintain a vibrant and active culture.

Fullan (2007) stated, "Failing to act when the environment around you is radically changing leads to extinction" (p. ix). A school leader must now be the catalyst for change, fostering continuous school improvement in the swiftly changing global society. The educational system "needs leaders who can create a fundamental transformation in the learning cultures of schools and the teaching profession" (Fullan, 2003, p. 92). According to Fullan, "effective leadership is in very short supply" (2007, p. xii). Already clear in the school leadership literature is that the functions of school leadership in general are related to student achievement; however, not as clear are the specific leadership characteristics, expertise, and content training that are correlated to student achievement. Hypothesized in this study was that the development of the categories of knowledge and expertise to perform the responsibilities identified extend far beyond leadership training (Waters, Marzano, \& McNutty, 2003). Also, given Tucker's (2011b) proposal that the ability to relate to children is among solutions for student achievement, this research explored leadership variables intended to address students' characteristics and needs. The educational backgrounds of school leaders were analyzed to determine whether concentration area (counseling, mathematics, language arts, etc.) and years of experience had a positive effect on student academic achievement. This study was designed to explore the need for connecting specific leadership behaviors more closely with student and school performance as a part of the focus on school effectiveness.

\section{Literature Review}

In this changing information age, the educational system must produce students who are critical thinkers and ready to compete in a global society. Due to the current economic environment, the education system has not been immune to the many budget cuts gripping the nation. As a result, many small schools are forced to operate with limited resources, including human and material resources. Sharratt and Fullan (2009) acknowledged that when schools are provided opportunities to increase their resources, including the skills and knowledge of teachers and administrators, students profit. Therefore, school leaders must have the skills that are necessary to meet the serious challenges in education that impact student and school success.

Very little research has been dedicated to studying the educational background of leaders and their expertise (Goldring, Spillane, Huff, Barnes, \& Supovitz, 2006). Among research with some linkage of educational background and expertise to leadership, Goldring et al. (2007) suggested that precursors to leadership behaviors include knowledge and skills, and personal characteristics, and that the amount of experience is a factor in assessing leadership. According to Leithwood, Louis, Anderson, and Wahlsrom (2004), some knowledge needed for effective leadership is situated or specific to the context of the learning experience and is acquired by participation with others in authentic, non-routine activities. Goldring et al. (2007), also noted that effective leaders have knowledge of content such that they insure rigor in content instruction.

STURGIS, SHIFLETT, \& TANNER / DOI: 10.5929/2017.7.1.8 
Previous literature has shown a relationship between educational background and enhanced student achievement. For example, Rafi and Samsudin (2007) conducted a study to examine the relationship between mathematics achievement and engineering. The researchers found that mathematics achievement affected students' performance in engineering drawing. Rafi and Samsudin referenced a previous study that also found students with greater previous mathematics achievement performed better than those with lower mathematics achievement (p. 54). Given the role of educational background and previous experience in achievement in other areas, this study focused on experiential knowledge as a precursor to effective leadership and explored whether the application of this knowledge had an effect on school ratings.

\section{Conceptual Framework}

The study was based on the premise that the principal's behavior and leadership expertise are influenced by not only knowledge acquired through training in school leadership, but also training in other content and exposure to real life experiences. Therefore, the study recognized the leader-center model inherent in the skills approach as described by Mumford, Zaccaro, Connelly, and Marks (2000). The skills approach or learner-centered model suggests that leadership performance is attributed to the leader's competencies, individual attributes, leadership outcomes, career experiences, and environmental influences. Mumford et al. (2000) maintained that at the core of the model are problem solving skills, social judgment skills, and knowledge representing leader competencies which are influenced by the leader's general cognitive ability, crystallized cognitive ability, motivation, personality, career experiences, and the environment.

Current researchers including Fullan (2008) adhere to both views of classical and post-behavioral theorists for guiding effective schools. Fullan suggested that successful management practices not only result from training, but also through experiences involving diverse settings and individuals. Researchers have defined approaches to leadership in different ways, and their definitions have implications for the role of school leadership. Each leadership approach or style suggests specific behaviors and actions expected of the principal. The skills-approach model encompasses elements of the theoretical constructs and approaches described in this research and support that leadership outcomes result from a leader's competencies in problem-solving skills, social judgment skills, and knowledge, all of which can be learned and developed through training and experience.

\section{Statement of the Problem}

There is lack of research dedicated to studying the educational background of leaders and the relationship of their training and expertise to school and student success (Goldring et al., 2006). More students from high poverty backgrounds are being left behind (Waits et al., 2006). They are graduating from high school unable to compete on the national and world stage. The data further showed that only $24 \%$ of the students tested are prepared for all four core curricular areas.

STURGIS, SHIFLETT, \& TANNER / DOI: 10.5929/2017.7.1.8 
Extensive studies have been conducted concerning the common practices of successful schools; however, questions remain as to why so few leaders have taken up the charge to emulate these successful schools and turn unsuccessful schools into successful ones (Waits et al., 2006). Also questionable is the influence of the leader's preparation in core curricular and other content areas on creating successful schools. Therefore, the purpose of the study addressed whether the educational background and experience are influential in the leader's effectiveness in school success, especially if the leader heads a small school with limited resources.

\section{Significance of the Study}

In urban school districts across the state of Texas, many small, high poverty, high minority (SHPHM) schools are struggling to provide their students with the resources needed to be successful and appropriately prepared for a global economy (TEA, n.d.). SHPHM schools are elementary schools with less than 500 students, middle schools with less than 750 students, and high schools with less than 1,500 students, consisting of at least a 50\% economically disadvantaged population and a $50 \%$ minority (African American and Hispanic) population. In addition, high minority schools have over $50 \%$ disadvantaged minority students (Shettle et al., 2005). It is becoming increasingly difficult to deal with the day-to-day realities of meeting the needs of the widely diverse populations that may exist in high poverty areas (Fullan, 2007; Smith, 1998). The problem of student performance or the lack thereof, persists year after year. According to the Texas Education Agency [TEA] website (n.d.), one urban Texas school district consisting of approximately 275 schools had only 15 schools receive a rating of "exemplary" during the 2006-2007 school-year. While many urban schools struggle with academic achievement, urban schools are capable of achieving academic success (Castagno, 2008; Reeves, 2004).

Reeves's (2004) research, described 90/90/90 schools as schools with a $90 \%$ economically disadvantaged student population, a 90\% minority population, and a $90 \%$ achievement rate (Reeves, 2004). Schools with high minority, high poverty populations and high achievement ratings do still exist. In these schools, the question becomes how much does the academic leader affect that success? According to the synthesis of research compiled by Barr and Parrett in 2007, topping the list of practices found in high-performing, high poverty schools is the capacity to ensure effective district and school leadership.

Leaders are now expected to be creative, flexible, and quick to respond to the ever-changing realities that exist outside of school. According to Isaacs (2003), principals are required to have certain skills to deal with their circumstances, oversee change, and improve student achievement. By taking a look at the educational backgrounds of leaders in small, high poverty, and high minority schools, the researchers examined whether there was a causal-comparative relationship between students' performance and the educational background and experience of the schools' leaders.

STURGIS, SHIFLETT, \& TANNER / DOI: 10.5929/2017.7.1.8 


\section{Method}

The purposive sampling used for participation originally targeted a potential population of 275 principals and assistant principals employed in small, high poverty, high minority (SHPHM) schools. The selection criterion that the principal or assistant principal had worked at the said campus for two or more years was expected to yield a sample size of 160 participants. However, at the time of data collection, the population changed because of attrition and other factors. This change resulted in a population of 147 individuals employed in schools meeting the criteria and a population of 139 individuals meeting the criterion related to the number of years employed at the sites. Of the number of eligible individuals, 57 agreed to participate.

\section{Instrument}

The Principals' and Assistant Principals' Self-Assessment Survey, a modified version of the Interstate School Leaders Licensure Consortium (ISLLC) Self-Assessment (CCSSO, 2000), was the instrument used. This instrument was administered online and consisted of 182 statements linked to indicators of the six categories of the 1996 ISLLC standards. Similar to previous reliability findings on the instrument, the reliability coefficients for each domain ranged from .74 to .88 .

The survey was organized into two sections: demographics and survey items. The demographics included variables that were measured against responses to survey knowledge items. These variables included type of training, years of experience, type of degree, and school rating. Knowledge items are those accepted as indicating successful leadership for schools and student achievement. The survey contained the overall question, "To what extent do I have current personal mastery (knowledge and understanding) of the following?" Ten knowledge domain items, which represent all six ISLLC standards, are arranged on the following 4-point Likert scale: 1 (little), 2 (some), 3 (sufficient), 4 (exemplary).

Unlike the original assessment, the items did not identify the standard by its number, but the key element of the standard introduced the item, and sample functions (indicators) of the item were listed to better guide the participants' understanding of the item.

\section{Data Analysis}

The independent variables of participants' educational background training and years of experience were given a number value. The campus rating also received a number value. In addition to descriptive statistics, the Chi Square Test of Independence was used to determine if there was a significant difference between the leader's concentration area and school rating, and the Chi Square Test of Independence was also used to determine if there was a significant difference between a leader's years of experience and school rating.

STURGIS, SHIFLETT, \& TANNER / DOI: 10.5929/2017.7.1.8 


\section{Results}

\section{Research Question/ Hypothesis 1}

The first research question guided an inquiry of the possibility of the existence of a relationship between the leader's concentration area (counseling, mathematics, language arts, science) and school rating. Responses to survey items pertaining to the first research question were analyzed through descriptive statistics as an initial approach to the question. The survey inquired of the participants' content areas for their undergraduate degrees. Two of 57 participants did not respond to this item. Undergraduate majors were categorized as education and non-education degrees. The most frequent content areas identified for education majors were elementary or early childhood $(n=7)$, secondary education $(n=6)$, physical education/health $(n=5)$, and social studies/history $(n=3)$. Non-education fields varied for the remaining 34 participants. These included science/math/engineering $(n=10)$; history/political science $(n=8)$; languages, literature, communications $(n=8)$; psychology $(n=4)$; technology/film $(n=2)$; and social work/bilingual studies $(n=2)$.

Additionally, the survey asked for participants' type and specialization of the degrees at the master's level. Three participants did not identify their degree type. Of those responding, the areas of specialization were educational leadership/administration $(n=31)$, curriculum and instruction $(n=9)$, guidance and counseling $(n=2)$, and other areas $(n=12)$. The final survey question asked for the current academic rating of the school. The Texas Education Agency (TEA) Standard Accountability System (2010) identified four ratings for school performance: exemplary, recognized, academically acceptable, and academically unacceptable. Each rating is based on the criterion of passing rates on the state's test (Texas Assessment of Knowledge and Skills (TAKS)) for the following content areas: reading/English/language arts; writing and social studies; mathematics; science; and all subjects combined. Table 1 shows the criteria set for the four school ratings and the number of participants employed in schools with each respective rating.

The null hypothesis generated to test research question one was as follows: $H_{0} 1$. There is no statistically significant difference between a leader's concentration area and school ratings. Table 2 contains the chi square and cross tabulated contingency coefficient statistical findings. These findings show that there was not a statistically significant difference between school ratings and academic concentrations based on Master's concentrations areas and undergraduate concentration areas. Therefore, hypothesis one was not rejected. 
Table 1

State Assessment (TAKS) Ratings and Criteria

\begin{tabular}{|c|c|c|c|c|c|c|}
\hline Rating & $\begin{array}{c}\text { All } \\
\text { Subjects } \\
\end{array}$ & $\begin{array}{c}\text { English/Reading/ } \\
\text { Language Arts }\end{array}$ & $\begin{array}{l}\text { Writing } \\
\text { and } \\
\text { Social } \\
\text { Studies }\end{array}$ & Mathematics & Science & Participants \\
\hline Exemplary & $\geq 90 \%$ & $*$ & $*$ & * & $*$ & $16.1 \%(9)$ \\
\hline Recognized & $\begin{array}{l}<90 \% \\
\text { and } \\
\geq 80 \%\end{array}$ & $*$ & $*$ & $*$ & $*$ & $33.9 \%(19)$ \\
\hline Acceptable & $*$ & $\begin{array}{c}<80 \% \text { and } \\
\geq 70 \%\end{array}$ & $\begin{array}{c}<80 \% \\
\text { and } \\
\geq 70 \%\end{array}$ & $\begin{array}{c}<80 \% \text { and } \\
\geq 60 \%\end{array}$ & $\begin{array}{c}<80 \% \text { and } \\
\geq 55 \%\end{array}$ & $37.5 \%(21)$ \\
\hline Unacceptable & $*$ & $<70 \%$ & $<70 \%$ & $<60 \%$ & $<55 \%$ & $12.5 \%(7)$ \\
\hline
\end{tabular}

Note. An asterisk $(*)=$ no criterion for the specific TAKS subject $(\mathrm{s})$

Table 2

Academic Concentrations and School Ratings

\begin{tabular}{lcccc}
\hline $\begin{array}{l}\text { Variable } \\
\text { Master's }\end{array}$ & Chi Square Value & df & $\begin{array}{l}\text { Symmetric } \\
\text { Value }\end{array}$ & Significance \\
$\begin{array}{l}\text { concentration/school } \\
\text { rating }\end{array}$ & 11.680 & 9 & .422 & .232 \\
$\begin{array}{l}\text { Undergraduate } \\
\text { concentration/school } \\
\text { rating }\end{array}$ & 2.753 & 3 & .218 & .431 \\
$\begin{array}{l}\text { Note. } n=54 \text { for master's concentrations and } n=55 \text { for undergraduate concentrations. } \\
p<.05 .\end{array}$
\end{tabular}

\section{Research Question/ Hypothesis 2}

The second research question examined the difference between the number of years of experience and the school rating. Of the participants identifying their years of experience, eight had two years, eight had three to five years, and 40 had more than five years of experience in the capacity of principal or assistant

STURGIS, SHIFLETT, \& TANNER / DOI: 10.5929/2017.7.1.8 
principal. In terms of their tenure at their current school, responses revealed that 23 participants had served in the administrative capacity for more than five years, 15 had served from three to five years, and 16 had been at the same school for two years. The null hypothesis generated to test research question two was as follows: $\mathrm{H}_{0} 2$. There is no statistically significant difference between a leader's number of years of experience and school ratings.

Data for the dependent variable, years of experience, were represented in this hypothesis and were analyzed through the chi square analysis. The statistics were analyzed for the following demographic questions: current years of experience, total years of experience, and school rating. The analysis involved cross tabulating these demographic items. The .05 level of significance was established as the region of rejection. The analysis determined that there were no significant differences between the groups representing total years of experience as an administrator and current school rating. The results for item five are reported in Table 3. There was, however, a significant difference found between the groups representing years served at the current school and the rating of the school as can be observed in Table 4.

Table 3

Chi Square Statistics: Total Years of Experience and School Rating

\begin{tabular}{lccc}
\hline & Value & $D f$ & Asymp. Sig. (2-sided) \\
\hline Pearson Chi Square & 10.246 & 6 & .115 \\
Likelihood ratio & 14.366 & 6 & .026 \\
Linear-by-linear & .139 & 1 & .709 \\
$N$ of valid cases & 56 & & \\
\hline$p<.05$. & & &
\end{tabular}

Table 4

Chi Square Statistics: Years of Experience at Current Site and School Rating

\begin{tabular}{lccc}
\hline & Value & $D f$ & Asymp. Sig. (2-sided) \\
\hline Pearson Chi-square & 19.172 & 6 & $.004^{*}$ \\
Likelihood ratio & 21.083 & 6 & .002 \\
Linear-by-linear & 8.194 & 1 & .004 \\
$N$ of valid cases & 54 & & \\
\hline
\end{tabular}

${ }^{*} p<.05$.

The statistics reported in Table 4 show that the frequencies for the number of years of experience at the current site and the rating of the school were statistically significant, $\chi^{2}(6, n=54)=.004, p<$. 05. These two variables are related, as one variable can be said to influence the other variable. More specifically, 
administrators with five or more years of experience at the present school seemed to be more likely to lead recognized schools, when compared to administrators with fewer than five years of experience. This is shown in Table 5 below. Therefore, the hypothesis was rejected.

Table 5

Chi Square Frequency Distribution

\begin{tabular}{|c|c|c|c|c|c|c|}
\hline \multirow{5}{*}{$\begin{array}{l}\text { How long have } \\
\text { you been the } \\
\text { principal or } \\
\text { assistant principal } \\
\text { of your current } \\
\text { school? }\end{array}$} & & \multicolumn{4}{|c|}{ What is the current academic rating of your campus? } & \multirow[b]{2}{*}{ Total } \\
\hline & & Exemplary & Recognized & $\begin{array}{l}\text { Academically } \\
\text { Acceptable }\end{array}$ & $\begin{array}{l}\text { Academically } \\
\text { Unacceptable }\end{array}$ & \\
\hline & 2 years & 0 & 3 & 9 & 4 & 16 \\
\hline & $3-5$ years & 4 & 2 & 8 & 1 & 15 \\
\hline & $\begin{array}{l}\text { More } \\
\text { than } 5 \\
\text { years }\end{array}$ & 3 & 14 & 4 & 2 & 23 \\
\hline Total & & 7 & 19 & 21 & 7 & 54 \\
\hline
\end{tabular}

\section{Discussion}

The purpose of this study was to examine the educational background of leaders in small, high poverty, high minority schools in an effort to determine if the education and experience of the school leaders are related to the academic success of the students. In addition, this study intended to provide a better understanding of whether special or additional skills are needed by these leaders in order for their schools to be successful. With respect to the overall research purpose, the results indicated that educational background, in terms of areas of concentrations, did not significantly impact school performance ratings. However, the principal having experience at the same site was found to be significant to positive school performance.

The tenure of a principal at the same site was significant to school performance was consistent with Fullan's (2008) observation that successful management practices not only result from training, but also through experiences. Further, this finding can be associated with Waters, Marzano, and McNutty's (2003) descriptions of the types of knowledge demonstrated by principals in effective schools, which were among the concepts upon which this study was based. The findings suggest that experience at the site enhances the principal's knowledge of what is important, what actions should be taken based on the environment, and how and when these actions should be implemented. The findings also support part of the views of Mumford et al. (2000) that suggested leadership performance is attributed to the leader's competencies, individual attributes, leadership outcomes, career experiences, and environmental influences. The results, 
however, could not definitively support Sharratt and Fullan's (2009) proposition that students profit when schools are provided opportunities to increase their resources, including the skills and knowledge of teachers and administrators.

\section{Conclusion}

\section{Implications}

The statistically significant finding of the study is that two or more years of experience at the current school has an impact on school rating and student performance. The literature on learning-centered leadership and effective performance of principals in low-performing, small, high poverty, high minority schools supports the conclusion that these schools fair better when the principal has the length of tenure required to make a positive impact on the school. Twenty-three of 54 responding participants had served at their current school more than five years. According to Seashore-Louis et al. (2010), five years is the average time needed for a principal to implement practices that will have a positive impact on school performance. Findings of the current study support that of Seashore-Louis and associates as the 40 principals with five or more years of total experience were more likely to be among the 49 higher performing schools in the study. Therefore, the longer the principal is in the position, the better able the principal should be to navigate through the various responsibilities, and the frequent practice of school districts transferring principals from one school to another prior to three years at the school site should be reconsidered.

School districts should also examine a leader's concentration area because, although there was no significant difference between a leader's concentration area and school rating, schools led by participants who specialized in Master's level educational leadership or administration had the highest ratings. And in terms of undergraduate majors, non-education majors were leaders in all types of school rating except for the rating of recognized. The specializations for many of these individuals included science, math, engineering, history, political science, languages, literature, communications, psychology, technology/film, and social work/bilingual studies. Therefore, the question of specific coursework and type of training needed for effective school leaders is becoming more prominent. Sparks (2013) reported that one principal preparation program leader maintained that among expectations of principals is to become academic leaders. This suggests that a principal would benefit from training experience in a content field that requires the completion of instructional leadership tasks.

\section{Limitations}

This research was limited to exploring training and experience of school leaders in one school district in the southeast region of Texas to address the research questions. Additionally, participants identified in this data report self-perceptions of their knowledge and skills; however, these perceptions may not truthfully address the intent of the standards from which the questions were extracted. Further, the sample may not have been representative of the population of principals in the district. Results of the study may only have implications for principals working in other districts and states whose characteristics

STURGIS, SHIFLETT, \& TANNER / DOI: 10.5929/2017.7.1.8 
and school status are similar to those investigated. The sample of participants was confined to the principals and assistant principals of Small High Poverty High Minority (SHPHM) schools; there may be principals that exhibit the same characteristics but are not in these schools. Purposive sampling is a potential threat to the study's validity. However, this threat was minimized or eliminated through the study's sampling frame which was based on the study's participant criteria.

\section{Future Research}

A replication of this study is recommended to be conducted in larger schools to compare findings and to determine the effects of skill and knowledge of principals in schools that are not characteristic of the schools included in the current study. Since a difference was found between ratings and tenure at academically acceptable and recognized schools, a qualitative study involving principals of these schools is recommended. Interviews and observations of both principals and teachers may reveal what leadership styles and leadership actions may be exposed as reasons for these differences.

The current study did not involve match pairs. Such a study would perhaps reveal additional information regarding which principals were prepared and experienced in content areas according to the level of school rating. Additionally, the pairing may contribute to knowledge of specific actions that were performed as linked to the standards.

\section{References}

Barth, R. (2006). Improving relationships inside the schoolhouse. Educational Leadership, 63(6), 8-13.

Barr, R. D., \& Parrett, W. H. (2007). The kids left behind: Catching up the underachieving children of poverty. Bloomington, IN: Solution Tree.

Castagno, A. E. (2008). Improving academic achievement, but at what cost? The demands of diversity and equity at Birch Middle School. Journal of Cases in Educational Leadership, 11(1), 1-9.

Council of Chief State School Officers. (2000). Interstate School Leaders Licensure Consortium (ISLLC) selfassessment. Retrieved from http://www.isllc self assessment rev ode[1].pdf

Fullan, M. (2003). Change forces with a vengeance. London: RoutledgeFalmer.

Fullan, M. (2007). Leading in a culture of change. New York: John Wiley.

Fullan, M. (2008). What's worth fighting for in the principalship? (2nd ed.). New York: Teachers College Press.

Goldring, E., Porter, A. C., Murphy, J., Elliott, S. N., \& Cravens, X. (2007). Assessing learning- centered leadership. Connections to research, professional standards, and current practices. Leadership and Policy in Schools, 8, 1-36. Retrieved from http://peabody.vanderbilt .edu/Documents/pdf/LSI/ 
Goldring, E. B., Spillane, J. P., Huff, J., Barnes, C., \& Supovitz, J. (2006). Measuring the instructional leadership competence of school principals. Paper presented at the 2006 meeting of the American Educational Research Association, San Francisco, CA.

Harris, A., \& Chrispeels, J. H. (Eds.). (2006). Improving schools and educational systems: International perspectives (contexts of learning). New York: Routledge.

Hawley, W. D. (Ed.). (2007). The keys to effective schools (2nd ed.). Thousand Oaks, CA: Corwin.

Issacs, A. J. (2003). An investigation of attributes of school principals in relation to resilience and leadership practices (Doctoral dissertation, Florida State University). Retrieved from www.WorldCat.org/etd.lib.fsu.edu

Leithwood, K., Louis, K. S., Anderson, S., \& Wahlsrom, K. (2004). How leadership influences student learning. New York: Wallace Foundation.

Mathews, J. (2011, December 11). No more excuses for U.S. schools. Washington Post [online]. Retrieved from http://www.washingtonpost.com

Mumford, M. D., Zaccaro, S. J., Connelly, M. S., \& Marks, M. A. (2000). Leadership skills: Conclusions and future directions. Leadership Quarterly, 11(1), 155-170.

National Governors Association Center for Best Practices, Council of Chief State School Officers. (2010). Common Core State Standards. Washington, DC: National Governors Association Center for Best Practices.

Rafi, A., \& Samsudin, K. A. (2007). The relationships of spatial experience, previous mathematics achievement, and gender with perceived ability in learning engineering drawing. Journal of Technology Education, 18(2), 53-67.

Reeves, D. B. (2004). Accountability in action: A blueprint for learning organizations (2nd ed.). Englewood, CO: Advanced Learning Press.

Seashore-Louis, K., Wahlstrom, K. L., Leithwood, K., \& Andersib, S.E. (2010). Investigating the links to improved student learning. The Wallace Foundation. Retrieved from http://www.wallacefoundation.org

Sharratt, L., \& Fullan, M. (2009). Realization. The change imperative for deepening district-wide reform. Thousand Oaks, CA: Corwin.

Shettle, C. Roey, S., Mordica, J., Perkins, R., Nord, C., Teodorovic, J., ...\& Brown, J. (2005). America's high school graduates: Results from the 2005 NAEP high school transcript study. Washington, DC: National Center for Education Statistics.

Smith, R. (1998). Principals for change: The development of moral/transformational leadership for urban schools. Dissertation Abstracts International, 59.

Sparks, S. D. (2013). States lack data on principals, study says most states lack data on school leaders' training, evaluation. Education Week Online, 32(20). Retrieved from www.edweek.org 
Spring, J. (2008). The American school from the Puritans to No Child Left Behind (7th ed.). Boston: McGraw Hill.

Texas Education Agency website. (n.d). School district data. Retrieved from www.tea.state.tx.us

Tucker, M. (2011a). Surpassing Shanghai. Cambridge, MA: Harvard Education Press.

Tucker, M. (2011b). Creating education success at home. Education Week, 31(8), 24-28.

Waits, M. J., Campbell, H. E., Gau, R., Jacobs, E., Rex, T., \& Hess, R. K. (2006). Why some schools with Latino children beat the odds... and others don't. Tempe, AZ: Morrison Institute for Public Policy School of Public Affairs, College of Public Programs Arizona State University and Phoenix, AZ: Center for the Future of Arizona.

Waters, T., Marzano, R. J., \& McNutty, B. (2003). Balanced leadership: What 30 years of research tells us about the effect of leadership on student achievement. Denver, CO: Mid-Continental Research for Education. Available from http://mcrel.org/balancedleadership

About the Authors

Kimberlin Sturgis, Ph.D. (sturgiskk@yahool.com) is a former elementary principal within Houston Independent School District. She is currently the Manager of Curriculum and Evaluation for the Children's Museum of Houston. She graduated with a Ph.D. in Educational Leadership from Prairie View A\&M University, located in Prairie View Texas. She received her Master of Education in Curriculum and Instruction at Prairie View A\&M University and her Bachelor of Science in Chemistry from Alcorn State University, located in Lorman, Mississippi. Kimberlin places an emphasis on perfecting educational leadership, utilizing her research talents, educational experiences, and professional experiences to guide educators and help develop their leadership skills. She has presented at conferences on topics related to the integration of technology into the classroom, intranet usage within education, the importance of being a culturally responsive educator and increasing diversity in STEM. As an educational leader, Kimberlin is devoted to researching methods to remediate leadership issues within K-12 public education.

Brittanee Shiflett, M.Ed. (brittanee007@gmail.com) is a doctoral student in the Educational Leadership Program at Prairie View A\&M University. She is currently employed as a school counselor within Bryan Independent School District. Brittanee received both her Master of Education in School Counseling and Bachelor of Science in Psychology from Sam Houston State University in Huntsville, Texas. Her research interests relate to developing cultural diversity preparatory programs for educational leaders, enhancing learning outcomes for culturally diverse learners, and researching methods to improve educational leadership.

Tyrone Tanner, Ed.D. (drtyronetanner@gmail.com) is a Professor of Education at Prairie View A\&M University and K-16 consultant. He has authored numerous books and articles ranging from helping parents become more involved with their children's learning, "Parents Need Help Too: A guide for parents of school-age children," to aiding teachers in effectively working with diverse learners, "Culturally

STURGIS, SHIFLETT, \& TANNER / DOI: 10.5929/2017.7.1.8 
Responsive Educational Theories: A practical guide with case studies for improving the academic performance of diverse learners." These products provide the framework for Dr. Tanner's mission and research. Dr. Tanner completed his doctoral studies in Educational Leadership and Cultural Studies at the University of Houston in Houston, Texas. He received his Master of Education in School Administration and Supervision from Southern University in Baton Rouge, Louisiana, and his Bachelor of Arts in History Education from Newberry College in Newberry, South Carolina. Dr. Tanner is currently a Professor in the Department of Administration and Counseling at Prairie View A\&M University. Early in his career, Dr. Tanner was a middle and high school teacher, middle and high school principal and central office school administrator. Dr. Tanner's research and philosophy are firmly planted in the belief that all students can learn, and if provided a culturally active classroom environment they can learn with exceptionality. As a father and educator, he believes parents want the best for their children, and with the right approach, the necessary trust can be created to build a powerful home and school partnerships. To that end, he is committed and dedicated to developing the tools necessary for educators and parents to experience success with all children.

STURGIS, SHIFLETT, \& TANNER / DOI: 10.5929/2017.7.1.8 